\title{
PENINGKATAN PENGETAHUAN POSISI KERJA (MANUAL HANDLING) DI TOKO/SUPERMARKET WILAYAH BANGUNTAPAN
}

\author{
Julian Dwi Saptadi, Machfudz Eko Arianto, Baiq Sukma Cholifia Setyaningrum \\ Fakultas Kesehatan Masyarakat, Universitas Ahmad Dahlan, Yogyakarta \\ e-mail: Machfudz.arianto@ikm.uad.ac.id
}

\begin{abstract}
Abstrak
Berdasarkan pemantauan yang telah dilakukan ditemukan beberapa permasalahan pada Keselamatan dan Kesehatan Kerja (K3) di supermarket/toko diantaranya yaitu, tingginya risiko Penyakit Akibat Kerja (PAK) yang diakibatkan oleh sikap kerja tidak aman yang dilakukan oleh pekerja supermarket/toko. Tujuan dalam pengabdian ini Melakukan identifikasi permasalahan Keselamatan dan Kesehatan Kerja (K3) pada supermarket/toko di wilayah Banguntapan, Kabupaten Bantul. Metode dalam pengabdian menggunakan desain studi yang digunakan pada yaitu kualitatif deskriptif. Dengan melakukan identifikasi perilaku dari pekerja supermarket/toko yang dapat menyebabkan Penyakit Akibat Kerja (PAK) dan Kecelakaan Akibat Kerja (KAK) dikarenakan sikap kerja yang salah di Supermarket/toko Wilayah Banguntapan Kabupaten Bantul Yogyakarta. Berdasarkan hasil yang telah diperoleh dan analisis yang dilakukan, penyakit kerja yang umum diderita dari kelima sampel supermarket/toko oleh pekerja adalah pegal-pegal. Hal tersebut disebabkan karena pada saat bekerja pekerja kurang memperhatikan posisi postur tubuh yang tepat, seperti pada saat mengangkat barang, menata, mengemas, dan mengetik. Alternatif pemecahan masalah yang dipilih dalam mengurangi permasalahan ergonomi terutama dalam aspek sikap kerja untuk mencegah terjadinya PAK (Penyakit Akibat Kerja) adalah dilakukannya intervensi dengan melakukan edukasi menggunakan media poster yang telah dibuat, para pekerja mampu memahami apa yang disampaikan.
\end{abstract}

Kata kunci: Ergonomi, Kesehatan Kerja, Manual Handling, dan Swalayan/toko,

\begin{abstract}
Based on the monitoring that has been carried out, there are several problems with occupational safety and health (K3) in supermarkets / shops, including the high risk of occupational diseases caused by unsafe working attitudes carried out by supermarket / shop workers. Identify Occupational Health and Safety (K3) problems in supermarkets / shops in the Banguntapan area, Bantul Regency. The study design used is descriptive qualitative. By identifying the behavior of supermarket / shop workers that can cause occupational diseases (PAK) and work-related accidents (KAK) due to wrong working attitudes in supermarkets / shops in Banguntapan area, Bantul regency, Yogyakarta. Based on the results that have been obtained and the analysis carried out, the common occupational diseases suffered by workers from the five samples of supermarkets / shops are aches. This is because at work, workers do not pay attention to proper posture, such as when lifting goods, arranging, packing, and typing. The alternative solution to the selected problem in reducing ergonomic problems, especially in the aspect of work attitudes to prevent the occurrence of PAK (Occupational Disease) is to do an intervention by conducting education using the poster media that has been made, the workers are able to understand what is being said.
\end{abstract}

Keywords: Ergonomics, Manual Handling, Occupational Health, and Supermarkets / Shops,

\section{PENDAHULUAN}

Kesehatan, keselamatan dan keamanan kerja adalah upaya perlindungan bagi tenaga kerja/pekerja agar selalu dalam keadaan sehat dan selamat selama bekerja di tempat kerja. Tempat kerja adalah ruang tertutup atau terbuka, bergerak atau tetap, atau sering digunakan/dimasuki oleh tenaga kerja/pekerja yang di dalamnya terdapat 3 unsur, yaitu: adanya suatu usaha; adanya sumber bahaya; adanya tenaga kerja/pekerja yang bekerja di dalamnya, baik secara terus menerus maupun hanya sewaktu-waktu (Triwibowo \& Pusphandani, 2013).

Penerapan K3 adalah untuk mengurangi atau mencegah kecelakaan yang mengakibatkan cidera atau kerugian materi. Karena itu, para ahli K3 berupaya mempelajari fenomena kecelakaan, faktor penyebab, serta cara efektif untuk mencegahnya. Upaya pencegahan kecelakaan kerja di Indonesia masih menghadapi berbagai kendala, salah satu diantaranya adalah pola pikir yang masih tradisional yang menganggap kecelakaan adalah sebagai musibah, sehingga masyarakat bersifat pasrah terhadap kecelakaan kerja yang menimpa mereka (Ramli, 2010). 
Ergonomi dapat didefinisikan sebagai suatu disiplin yang mengkaji keterbatasan, kelebihan, serta karakteristik manusia, dan memanfaatkan informasi tersebut dalam merancang produk, mesin, fasilitas, lingkungan, dan bahkan sistem kerja, dengan tujuan utama tercapainya kualitas kerja yang terbaik tanpa mengabaikan aspek kesehatan, keselamatan, serta kenyamanan manusia penggunanya. Mengacu pada definisi ini, dapat dikatakan bahwa hampir semua objek rancangan yang berhubungan dengan manusia memerlukan ilmu ergonomi (Irridiastadi dan Yassierli, 2014).

Penyakit Akibat Kerja (PAK) dan Kecelakaan Kerja (KK) di kalangan masyarakat di Indonesia belum tercatat dengan baik. Jika dilihat angka kecelakaan dan penyakit akibat kerja di beberapa negara maju (dari beberapa pengamatan) menunjukkan kecenderungan peningkatan prevalensi. Sebagai faktor penyebab, sering terjadi karena kurangnya kesadaran pekerja dan kualitas serta keterampilan pekerja yang kurang memadai. Banyak pekerja yang meremehkan risiko kerja, sehingga tidak menggunakan alatalat pengaman walaupun sudah tersedia. Penjelasan Undang-Undang Nomor 23 Tahun 1992 tentang Kesehatan telah mengamanatkan antara lain, setiap tempat kerja harus melaksanakan upaya kesehatan kerja, agar tidak terjadi gangguan kesehatan pada pekerja, keluarga, masyarakat dan lingkungan disekitarnya. (Riyadina et al, 2013) Penyakit akibat kerja disebabkan oleh dua faktor, yaitu lingkungan kerja dan hubungan kerja. Penyakit akibat kerja atau berhubungan dengan pekerjaan dapat disebabkan oleh pemajanan di lingkungan kerja. (Wichaksana A, 2012).

Posisi kerja ergonomi adalah posisi keja tenaga kerja yang disesuaikan dengan jenis pekerjaannya dan sarana kerja, sehingga dapat menghindarkan pekerja berkerja dengan posisi membungkuk, Kristanto (2011). Pencapaian keselamatan dan kesehatan kerja tidak lepas dari peran ergonomi, karena ergonomi berkaitan dengan orang yang bekerja, selain dalam rangka efektivitas, efisiensi dan produktifitas kerja (Tarwaka, 2010). Perhitungan beban kerja dalam sebuah perusahaan sangat penting. Beban kerja (workload) mengacu pada intensitas penugasan kerja. Ini merupakan sumber stres karyawan (Shah et al., 2011).

Wilayah Desa Banguntapan terdapat 1 desa dengan 11 dusun. Jumlah penduduk dari data Dinas Kependudukan Daerah Istimewa Yogyakarta sebanyak 37.726 jiwa (Laki-laki 18.882 jiwa atau 50,05 \% dan perempuan 18.844 jiwa atau 49,95 \%) dengan jumlah kepala keluarga 12.240 KK (KK laki-laki : 9.934 KK dan KK perempuan : 2.306 KK). Berdasarkan deskripsi dan pemantauan yang telah dilakukan ditemukan beberapa permasalahan pada Keselamatan dan Kesehatan Kerja (K3) di supermarket/toko diantaranya yaitu, tingginya risiko Penyakit Akibat Kerja (PAK) yang diakibatkan oleh sikap kerja tidak aman yang dilakukan oleh pekerja supermarket/toko. Sikap kerja yang tidak baik termasuk ke dalam permasalahan ergonomi yaitu manual handling yang dilakukan dalam jangka waktu lama dan dengan posisi yang salah.

\section{METODE}

Metode yang diterapkan dalam program kegiatan pengabdian masyarakat ini adalah dengan menggunakan ceramah dan poster. Poster yang diberikan berkaitan dengan masalah ergonomic yaitu manual handling. Kami juga menjelaskan isi dari media yang diberikan secara singkat kepada para pekerja, dengan tujuan agar para pekerja lebih memahami isinya. Kegiatan pemberian poster dilakukan dalam waktu satu hari karena tidak membutuhkan waktu yang lama. Kegiatan ini dilakukan Bersama dengan 1 mahasiswa Fakultas Kesehatan Masyarakat (FKM). Sasaran dalam kegiatan pengabdian ini adalah para pekerja bengkel yang berada di wilayah Banguntapan. 


\section{HASIL DAN PEMBAHASAN}

1. Berdasarkan faktor risiko di tempat kerja

Tabel 1. Faktor Risiko di Tempat Kerja

\begin{tabular}{|c|c|c|c|c|c|c|}
\hline \multirow[b]{2}{*}{ No. } & \multirow[b]{2}{*}{$\begin{array}{l}\text { Faktor Risiko di } \\
\text { Tempat Kerja }\end{array}$} & \multicolumn{5}{|c|}{ Nama Perusahaan } \\
\hline & & $\begin{array}{c}\text { Diva } \\
\text { Swalayan }\end{array}$ & $\begin{array}{l}\text { Toyota } \\
\text { Janti }\end{array}$ & $\begin{array}{c}\text { Alfamart } \\
\text { Jl.Gedongkuning } \\
1\end{array}$ & $\begin{array}{c}\text { Alfamart } \\
\text { Jl.Gedongkuning } \\
2\end{array}$ & $\begin{array}{c}\text { BJ } \\
\text { Home }\end{array}$ \\
\hline 1. & Fisik & Ya & Tidak & Ya & Ya & Ya \\
\hline 2. & Kimia & Tidak & Tidak & Tidak & Tidak & Ya \\
\hline 3. & Biologi & Tidak & Tidak & Tidak & Tidak & Tidak \\
\hline 4. & Ergonomi & $\mathrm{Ya}$ & $\mathrm{Ya}$ & Ya & Ya & Ya \\
\hline 5. & Psiko Sosial & Tidak & Tidak & Tidak & Tidak & Tidak \\
\hline 6. & $\begin{array}{l}\text { Kecelakaan } \\
\text { Kerja }\end{array}$ & Ya & Tidak & Tidak & Tidak & Ya \\
\hline
\end{tabular}

Sumber : Data Primer (2020)

Risiko adalah kombinasi antara kemungkinan terjadinya suatu kejadian dan keparahan akibat potensi dari bahaya yang ada (ECAST, 2009). Berdasarkan tabel 1. Faktor risiko fisik di tempat kerja didapatkan pada empat supermarket/toko yang meliputi, Diva Swalayan, Alfamart Jl. Gedongkuning 1, Alfamart Jl. Gedongkuning 2, dan BJ Home. Sedangkan supermarket/toko yang tidak ditemukan faktor risiko fisiknya adalah di Toyota Janti. Lingkungan fisik kerja adalah segala sesuatu yang berada pada area kerja yang dapat berdampak/berpengaruh kepada karyawan baik terjadi secara langsung maupun tidak langsung, keadaan lingkungan fisik yang umum terdapat suatu dampak masalah pada perusahaan meliputi keadaan tekanan panas, pencahayaan, kebisingan, dan getaran.

Faktor risiko fisik yang ditemukan di Diva Swalayan adalah adanya debu karena ventilasi yang kurang baik. Dampak dari debu dan ventilasi yang kurang baik ialah kualitas udara yang buruk berisiko menyebabkan beragam gangguan kesehatan, seperti batuk, sakit tenggorokan, mata berair, atau sesak napas. Seorang penderita asma mungkin akan mengalami serangan asma. Dalam jangka panjang, kualitas udara buruk dapat menyebabkan penghuni rumah mengalami flu yang tidak kunjung sembuh, bronkitis, sakit kepala yang terus berulang, dan asma yang sering kambuh. Supermarket/toko yang terlalu lembap menyebabkan pertumbuhan jamur, dan bahkan dalam jangka panjang dapat menyebabkan kerusakan bangunan.

Faktor risiko fisik yang terdapat pada Alfamart Jl. Gedongkuning 1 (29.1으) dan Alfamart Jl. Gedongkuning $2(27,5 \circ \mathrm{C})$ adalah suhu udara nya yang dingin karena sirkulasi udara nya berasal dari AC karna menurut PERMENAKER 05 tahun 2018 kadar suhu ruangan yang dipersyaratkan sebesar 18ㄷ30 ․ C. Sedangkan di BJ Home ditemukan faktor risiko fisik berupa kebisingan dari kendaraan yang keluar masuk maupun kendaraan yang berlalu lalang di jalan raya sebesar 74,3 dBA. Menurut Peraturan Menteri Kentenagakerjaan No. 5 tahun 2018 nilai ambang batas kebisingan dalam waktu pemaparan 8 jam per hari intensitas kebisingan nya maksimal $85 \mathrm{dBA}$. Oleh karena itu, BJ Home termasuk ke dalam kategori bising sedangkan untuk keempat supermarket/toko lainnya tidak termasuk ke dalam kategori tersebut.

Kebisingan adalah semua suara yang tidak dikehendaki yang bersumber dari alat-alat proses produksi dan atau alat-alat kerja yang pada tingkat tertentu dapat menimbulkan gangguan pendengaran (PER.13/MEN/X/2011). Pengaruh pemaparan kebisingan intensitas tinggi (di atas NAB) adalah terjadinya kerusakan pada indera pendengaran yang dapat menyebabkan penurunan daya dengar baik yang 
bersifat sementara maupun bersifat permanen atau ketulian. Sebelum terjadi kerusakan pendengaran yang permanen, biasanya didahului dengan pendengaran yang bersifat sementara yang dapat mengganggu kehidupan yang bersangkutan baik di tempat kerja maupun di lingkungan keluarga dan lingkungan sosialnya. Secara fisiologis, kebisingan dengan intensitas tinggi dapat menyebabkan gangguan kesehatan seperti, meningkatnya tekanan darah dan denyut jantung, risiko serangan jantung meningkat, gangguan pencernaan.

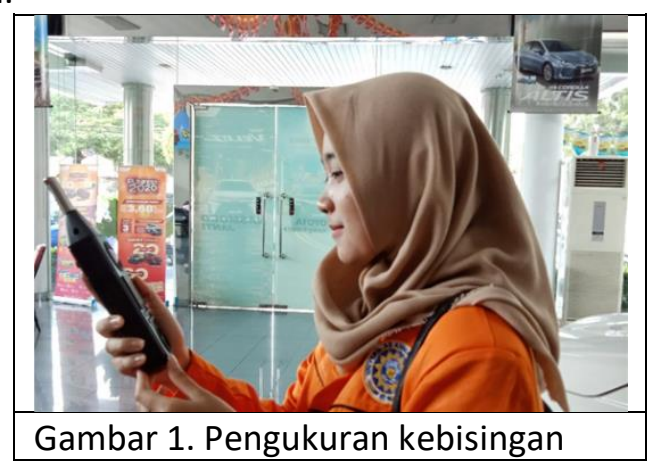

Berdasarkan tabel 1. Supermarket/toko yang memiliki adanya faktor risiko kimia adalah BJ Home. BJ Home merupakan supermarket yang menjual alat dan bahan-bahan bangunan sehingga banyak komponen yang mengandung bahan kimia seperti cat, semen, dan berbagai bahan bangunan lain. Sedangkan di keempat supermarket/toko lain tidak ditemukan adanya faktor risiko kimia. Solvent yang banyak digunakan dalam komponen antiseptik, desinfektan dikenal sebagai zat yang paling karsinogen atau yang bersifat racun. Semua bahan cepat atau lambat ini dapat memberi dampak negatif terhadap kesehatan mereka. Gangguan kesehatan yang paling sering adalah dermatosis kontak akibat kerja yang pada umumnya disebabkan oleh iritasi (amoniak, dioksan) dan hanya sedikit saja oleh karena alergi (keton). Bahan toksik (trichloroethane, tetrachloromethane) jika tertelan, terhirup atau terserap melalui kulit dapat menyebabkan penyakit akut atau kronik, bahkan kematian. Bahan korosif (asam dan basa) akan mengakibatkan kerusakan jaringan yang irreversible pada daerah yang terpapar. Kelima supermarket/toko tidak ditemukan adanya faktor risiko biologi dan faktor risiko psikososial. Dampak bagi pekerja yang berkaitan dengan bahan-bahan atau material berbahaya (kimia) antara lain yaitu debu atau gas yang menyebebabkan penyakit paru-paru, cairan mental dapat menumbuhkan bakteri dan jamur yang menyebabkan penyakit dermatitis dan asma, semen yang menyebabkan camical burns.

Berdasarkan tabel 1. Faktor risiko ergonomi ditemukan di kelima supermarket/toko yang dijadikan sampel. Faktor risiko ergonomi yang ditemukan di semua supermarket/toko tersebut adalah sikap kerja yang dilakukan saat melakukan pekerjaan kurang tepat, misalnya saat mengangkat dan mengangkut barang, mengetik, dan mengemas barang. Selain itu, pekerja bagian kasir melakukan pekerjaannya dengan posisi berdiri namun letak mesin kasirnya yang terlalu rendah sehingga sikap kerja yang dilakukan tersebut kurang tepat. Berikut ini beberapa efek negatif bagi pekerja karena supermarket/toko tidak menerapkan ergonomi yaitu, kelelahan, mengabaikan cara mengetik yang baik, duduk sembarangan akan rentan mengalami kelelahan. Tata letak kursi yang terlalu pendek atau terlalu tinggi akan membuat mengetik menjadi tidak nyaman, dan penyakit dapat timbul karena lelah yang terus menerus tanpa ada pengobatan. Melihat layar komputer secara terus menerus awalnya akan membuat mata lelah, jika kelelahan itu dibiarkan terus menerus maka dapat menimbulkan kerusakan pada mata. Hal tersebut dapat terjadi pada bagian tubuh yang lain, baik itu pinggang, kaki, leher, maupun kepala.

Posisi tubuh dalam kerja sangat ditentukan oleh jenis pekerjaan yang dilakukannya. Setiap posisi kerja mempunyai manfaat yang berbeda terhadap tubuh. Beberapa jenis pekerjaan akan memerlukan sikap dan posisi tertentu yang kadang tidak nyaman. Kondisi kerja seperti ini memaksa pekerja selalu berada pada sikap dan posisi kerja yang tidak wajar dan terkadang berlangsung dalam jangka waktu yang lama. Hal ini tentu akan mengakibatkanpekerja cepat lelah, membuat banyak kesalahan atau menderita cacat tubuh (Anggraeni, 2015). 


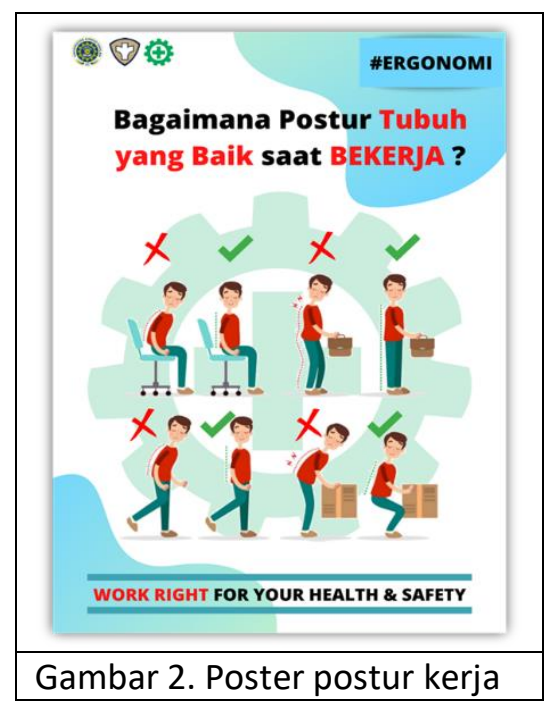

Posisi pelayanan kerja dengan posisi duduk, tentunya tidak dapat digeneralisasi sebab tukang tik yang meghadap monitor dengan penuh konsentrasi, akan berbeda dengan tukang jahit manual, atau dengan pengrajin pengasah batu akik. Ditinjau dari aspek kesehatan, bekerja pada posisi duduk yang memerlukan waktu lama dapat menimbulkan otot perut semakin elastis, tulang belakang melengkung, otot bagian mata terkonsentrasi sehingga cepat merasa lelah. Kejadian tersebut, jika tidak diimbangi dengan rancangan tempat duduk yang tidak memberikan keleluasaan gerak atau alih pandang yang memadai tidak menutup kemungkinan terjadi gangguan bagian punggung belakang, ginjal atau mata. Duduk memiliki sejumlah keuntungan dibandingkan dengan berdiri. Tubuh lebih baik karena beberapa dukungan yang dapat digunakan, seperti lantai, kursi, sandaran, sandaran tangan, permukaan mejakerja. Oleh karena itu, posisi duduk tubuh relatif dapat mengurangi kelelahan daripada berdiri (Kuswana, 2014).

Posisi kerja sambil berdiri merupakan metode yang sering digunakan dalam berbagai aktivitas di bidang industri. Banyak industri yang menerapkan sistem kerja dengan mengharuskan pekerja melakukan pekerjaannya dengan sikap berdiri sepanjang periode kerja. Orientasinya hanyalah untuk suatu pencapaian hasil produksi yang tinggi. Sikap kerja berdiri mempunyai beberapa kelebihan, terutama sikap kesiagaan lebih terjaga daripada duduk. Bekerja dengan sikap berdiri untuk periode yang lama, berdiri di atas lantai yang keras merupakan pekerjaan yang berat dan dapat mengakibatkan kenyerian pada pinggang, ketegangan pada kaki dan betis, kelelahan pada otot sistem musculoskeletal, dan gangguan kesehatan lainnya (Tarwaka, 2014).

Pekerja yang memiliki pengetahuan yang kurang tentang cara bekerja dan keselamatan kerja dapat menimbulkan penyakit akibat kerja. (Sarinah, 2015). Selain itu, perilaku seseorang seringkali dipengaruhi oleh tingkat pengetahuannya. (Yasari, 2011). Pengetahuan seseorang tentang faktor bahaya, sumber bahaya dan jenis bahaya di tempat kerja yang kurang akan berdampak pada kesadaran untuk melindungi diri dari berbagai macam potensi bahaya kerja. (Husaini, 2014).

Masa kerja berhubungan langsung dengan pengalaman kerja, semakin lama masa kerja seseorang maka semakin tinggi pengalaman dan jam terbang pekerja tersebut, sehingga pekerja akan mampu lebih memahami tentang cara bekerja dengan aman untuk menghindarkan diri mereka dari penyakit akibat kerja. Tenaga kerja yang baru umumnya belum mengetahui secara mendalam seluk beluk pekerjaan. Sebaliknya dengan bertambahnya masa kerja seseorang tenaga kerja maka bertambah pula pengetahuan dan keterampilan yang dimiliki pekerja dan aspek keselamatan dari pekerjaan yang dilakukan. (Moradinazar M, et al, 2013).

Seseorang dapat bekerja dengan baik dalam sehari selama 8 jam atau 40 jam dalam seminggu. Waktu sisa dalam satu hari (16 jam) dipergunakan untuk kehidupan dalam keluarga dan masyarakat, 
istirahat dan lain-lain. Jam kerja dapat memengaruhi penyakit akibat kerja, karena jam kerja yang lama dapat menyebabkan kelelahan dan memperbesar risiko penyakit akibat kerja. (Cecep, 2014).

\section{SIMPULAN}

Berdasarkan hasil dari kegiatan pengabdian ini dapat disimpulkan bahwa:

1. para karyawan supermarket/toko banyak belum mengetahui posisi mengangkat barang yang benar sehingga cepat mengalami kelelahan bahkan sering merasa pegal pada area punggung.

2. Prioritas masalah K3 pada supermarket/toko di wilayah Banguntapan III Bantul, Yogayakarta adalah bahaya dari faktor ergonomi yaitu sikap kerja yang tidak aman yang dilakukan pekerja.

3. kegiatan Intervensi terkait dengan pemecahan masalah tingginya risiko Penyakit Akibat Kerja (PAK) yang diakibatkan oleh sikap kerja tidak aman yang dilakukan oleh pekerja supermarket/toko wilayah Banguntapan, Kabupaten Bantul menggunakan media poster

\section{DAFTAR PUSTAKA}

Anggraeni, V.D. 2015. Laporan Umum Praktik Kerja Lapangan PT. Indo Acidatama Tbk, Kemiri, Kebakkramat, Karanganyar. Yogyakarta: Jurusan Kesehatan Lingkungan Politeknik Kesehatan.

Dinas Kesehatan Kabupaten Bantul. 2018. Profil Kesehatan Kabupaten Bantul. Yogyakarta.

European Commercial Aviation Safety Team., 2009. Safety Management System and Safety Culture Working Group - Guidance on Hazard Identification. ESSI.

Husaini. 2014. Relationship Exposure CO, SO2, NO2, Fume and Vapor with Lung Function and Immunoglobulin Serum levels of Blacksmith. Disertation of Doctoral Program-Medicine and Health Sciences Graduate Program of the Faculty of Medicine, University of Gadjah Mada. Indonesia. 54-55.

Iridiastadi, H., Yassierli. 2014. Ergonomi Suatu Pengantar. Bandung: PT. Remaja Rosdakarya.

Kristanto, 2011, Faktor Kejadian Low Back Pain Pada Operator Tembaga Sebuah Tambang Nikel di Sulawesi, Journal Promosi Kesehatan Indonesia, Vol 04 (02).

Kuswana, WS. 2014. Ergonomi Dan Kesehatan dan Keselamatan Kerja. Bandung: PT. Remaja Rosdakarya.

Moradinazar M, et al. Epidemiology of Work-Related Injuries Among Construction Workers of Ilam (Western Iran) During 2006-2009. Journal of Iran Red Crescent Med 2013;15: e8011.

Peraturan Menteri Ketenagakerjaan No. 5 tahun 2018.

Peraturan Menteri Kesehatan Republik Indonesia Nomor 1077/MENKES/PER/V/2011 Tentag Pedoman Penyehatan Udara Dalam Ruang Rumah.

Peraturan Menteri Tenaga Kerja dan Transmigrasi Republik Indonesia Nomor PER.13/MEN/X/2011 Tentang Nilai Ambang Batas Faktor Fisika dan Faktor Kimia Di Tempat Kerja.

Ramli, Soehatman. 2010.“Petunjuk Praktis Manajemen Kebakaran (Fire Manajement)”. Dian Rakyat. Jakarta.

Riyadina W, Suharyanto FX, and Tana L. 2013. Keluhan Nyeri Muskuloskeletal pada Pekerja Industri di Kawasan Industri Pulo Gadung Jakarta. Majalah Kedokteran Indonesia. 58(1).

Sarinah B.K and Supri E. 2015. Hubungan Pengetahuan dan Sikap Kesehatan Kerja dengan Penyakit Akibat Kerja pada Pekerja Batu Bata. Jurnal Kesehatan Masyarakat.1(2).

Shah, S.S.H., Jaffari, A.R., Aziz, J., Ejaz, W., Ul-Haq, I., \& Raza, S.N. 2011. Workload and Performance of Employees. Interdisciplinary Journal of Contemporary Research in Business, 3 (5): 256-267.

Tarwaka. 2010. Ergonomi Industri: Dasar-Dasar Pengetahuan Ergonomic dan Aplikasi di Tempat Kerja. Cetakan Kedua. Surakarta: Harapan Press Solo.

Tarwaka. 2014. Keselamatan dan Kesehatan Kerja: Manajemen dan Implementasi K3 di Tempat Kerja. Surakarta: Harapan Press. 
Wichaksana A. 2012. Penyakit Akibat Kerja di Rumah Sakit dan Pencegahannya. Cermin Dunia Kedokteran.

Yasari. 2011. Perilaku Penggunaan Alat Pelindung Diri dan Kejadian Dermatitis Akibat Kerja pada Pekerja Pengangkut Sampah di PT. USB Kota Jambi. Tesis. Yogyakarta: Universitas Gadjah Mada. 